\title{
NOTA/NOTE
}

\section{Llenando un vacío: primer registro del gastrópodo neritáceo sin concha Titiscania limacina Bergh, 1890 en Colombia}

\section{Filling a gap: first record of the shell-less neritacean gastropod Titiscania limacina Bergh, 1890 in Colombia}

\author{
Edgardo Londoño-Cruz \\ (iD) $0000-0001-5762-9430$
}

Grupo de Investigación en Ecosistemas Rocosos Intermareales y Submareales Someros (Lithos), Departamento de Biología, Universidad del Valle, Cali, Colombia.edgardo.londono@correounivalle.edu.co

\section{RESUMEN}

$\mathrm{E}$ 1 registro de la biodiversidad marina es una tarea fundamental y la distribución de las especies está en el centro de ella. Este documento corresponde al primer registro de Titiscania limacina, un neritaceo sin concha, en Colombia. Esta especie fue encontrada en el intermareal de un ecosistema rocoso del Parque Nacional Natural Gorgona, en la costa Pacífica. Este descubrimiento llena un vacío en la distribución de la especie en el Pacífico Oriental Tropical y hace un llamado al monitoreo de la biodiversidad, lo cual puede, dado el potencial de esta costa colombiana poco estudiada, producir más e interesantes hallazgos de nuevas especies para la región, en particular, o para la ciencia, en general.

PALABRAS CLAVE: Pacífico Oriental Tropical, isla Gorgona, babosa de mar

\section{ABSTRACT}

$\mathrm{R}$ ecording marine biodiversity is a fundamental task and species distributions are at the very core of it. This paper is the first report of Titiscania limacina, a shell-less neritacean, in Colombia. This species was recorded in the intertidal of a rocky ecosystem at Gorgona National Natural Park, Pacific coast. This discovery fills a gap of this species distribution in the Tropical Eastern Pacific and calls attention to biodiversity monitoring, given the potential of this understudied Colombian coast to produce more and interesting findings of new species for the region, in particular, or for science, in general.

KEYWORDS: Tropical Eastern Pacific, Gorgona Island, sea-slug 
Los humanos siempre se han preguntado cuál es el número de especies (riqueza) que habita el planeta Tierra. Aunque este pregunta es casi imposible de resolver, en el dominio terrestre y para grandes animales (v. g. maníferos y reptiles) y plantas la respuesta podría estar relativamente completa. Sin embargo, en el dominio marino y para pequeños animales y plantas, esta podría ser más difícil de conseguir. Muchos investigadores han tratado de resolver esta tarea ( $\mathrm{v} . \mathrm{g}$. Foggo et al., 2003; Bouchet, 2006; Miloslavich et al., 2011; Mora et al., 2011; Appeltans et al., 2012) con diferencias sorprendentes en sus estimaciones. En su capítulo, Bouchet (2006) argumenta que los grupos más comunes de organismos marinos, como los moluscos, están alcanzando su número estimado de especies, pero en una publicación más reciente, Bouchet et al. (2016) mencionan que el número de nuevas especies de moluscos que todavía faltan por describir es tres veces mayor que el número actual de especies conocidas y descritas (150 000 vs. 50000 ) y que, al ritmo actual, tomaría al menos 300 años nombrar todos los moluscos que habitan el planeta. Por lo tanto, incluso en grupos bien conocidos, no es raro encontrar registros de especies nuevas para la ciencia (v. g. Tan and Liu, 2001; Tamsouri et al., 2014) o documentar la extensión de los rangos de distribución - nuevos registros regionales (v. g. Valencia-Giraldo et al., 2015; Muñoz and Londoño-Cruz, 2016; Londoño-Cruz et al., 2018), en regiones donde escasean especialistas, esfuerzos de investigación o ambos.

Los moluscos, uno de los grupos animales más ricos y abundantes del reino marino, incluyen, entre otros, a los caracoles (clase Gastropoda), algunos de los cuales han perdido parcial o completamente su concha. Los caracoles con esta característica son conocidos, por lo general, como babosas marinas y la mayoría están confinados a la subclase Heterobranchia. Una excepción notable es el género Titiscania Bergh, 1890, que pertenece a la subclase Neritimorpha. Los parientes más cercanos a esta excepción son los caracoles de conchas fuertes del género Neritiopsis Grateloup, 1832 y Nerita Linnaeus, 1758, caracoles comunes del intermareal de las costas rocosas. El género Titiscania (Neritopsidae) comprende dos especies: $T$. shinkishihataii y $T$. limacina. La primera fue descrita originalmente en Japón y está restringida a Asia oriental mientras que la última ha sido registrada en varias regiones a lo largo del Indo-Pacífico (GBIF Secretariat, 2019). Además de los registros en el GBIF, se conocen dos registros adicionales: uno de Kodiaghat y Burmanallah en India (Apte y Nerurkar, 2016) y otro de Puerto Ayora, Santa Cruz, islas Galápagos, Ecuador (Templado y Ortea, 2001). En el Pacífico Oriental Tropical (POT), esta especie ha sido
Humans have always wondered what the number of species (richness) inhabiting planet Earth is. Although this question is almost unsolvable, in the terrestrial realm and for large animals (e.g., mammals and reptiles) and plants, the answer could be relatively complete. In the marine realm and for small animals and plants, however, it could be more difficult to achieve. Many researchers have tried to solve this task (e.g., Foggo et al., 2003; Bouchet, 2006; Miloslavich et al., 2011; Mora et al., 2011; Appeltans et al., 2012) with striking differences in their estimations. In his chapter, Bouchet (2006) argues that the most common groups of marine animals, like the mollusks, are reaching their estimated number of species, but in a more recent publication, Bouchet et al. (2016), mention that the number of new species of mollusks yet to be described is three times larger than the current number of known and described species (150 000 vs. 50 000) and that at the current pace, it will take at least 300 years to name all the mollusks inhabiting the planet. Hence, even in well-known groups, it is not rare to find records of species new to science (e.g., Tan and Liu, 2001; Tamsouri et al., 2014) or to document the extension of species' range distributions - new regional records (e.g., Valencia-Giraldo et al., 2015; Muñoz and Londoño-Cruz, 2016; Londoño-Cruz et al., 2018), in regions where specialists or research efforts or both are scarce.

The mollusks, one of the richest and more abundant animal groups in the marine realm, include among others, the snails (class Gastropoda), some of which have partially or completely lost their protective shells. The snails with this characteristic are usually known as sea-slugs and most are confined to the subclass Heterobranchia. One remarkable exception is the genus Titiscania Bergh, 1890, belonging to the subclass Neritimorpha. The closest relatives to this exception are the heavily shelled snails of the genera Neritiopsis Grateloup, 1832 and Nerita Linnaeus, 1758, which are common intertidal snails of the rocky shores. The genus Titiscania (Neritopsidae) comprise two species: $T$. shinkishihataii and T. limacina. The former was originally described from Japan and is restricted to East Asia, while the latter has been reported in several regions across the IndoPacific (GBIF Secretariat, 2019). Apart from the records in the GBIF, two other are available: one from Kodiaghat and Burmanallah in India (Apte and Nerurkar, 2016) and the other from Puerto Ayora, Santa Cruz, Galápagos Islands, Ecuador (Templado and Ortea, 2001). In the Tropical Eastern Pacific (TEP), this species has been reported only in México, Costa Rica, Panamá, and Ecuador. Hence, this is the first record of this species in Colombia (in Gorgona island), which along 
registrada solo en México, Costa Rica, Panamá y Ecuador. Por lo tanto, este es el primer registro en Colombia, en isla Gorgona que, junto con islas de los últimos tres países mencionados (isla Cocos en Costa Rica, isla Coiba en Panamá e islas Galápagos en Ecuador más la isla colombiana de Malpelo), conforma el corredor marino del POT.

Durante una campaña de campo para el monitoreo de los ecosistemas rocosos, usando el protocolo SARCE (2012) del Parque Nacional Natural Gorgona (Figura 1), el 31 de agosto de 2019 se encontró un espécimen de babosa marina blanca en forma de nudibranquio bajo una roca de $38 \times 22 \mathrm{~cm}$ aproximadamente, en el intermareal bajo del sitio conocido localmente como Playa Verde $\left(2,947517^{\circ} \mathrm{N}\right.$; $\left.-78,198133^{\circ} \mathrm{W}\right)$. El espécimen fue recolectado y almacenado en un recipiente plástico con agua de mar. Posteriormente, se observó bajo estereomicroscopio y se fotografió (Figura 2), tras lo cual el espécimen fue relajado con la adición gradual de agua dulce al recipiente y, después de la muerte, fijado y preservado en etanol al $97 \%$. En el laboratorio el espécimen fue medido, fotografiado y almacenado en la Colección de Referencia de Organismos Marinos (Departamento de Biología, Universidad del Valle, Cali, Colombia). with islands of the last three countries (Cocos Island, Costa Rica; Coiba Island, Panamá; Galápagos Islands, Ecuador, plus the Colombian Malpelo Island) constitutes the Marine Corridor of the TEP.

During a field campaign in 2019/08/31 for monitoring of the rocky shore ecosystems, using SARCE protocol (2012), at the Gorgona National Natural Park (Figure 1), one specimen of a white nudibranch-like seaslug was found underneath a rock of approximately $38 \times$ $22 \mathrm{~cm}$ in the low intertidal of the site known as Playa Verde $\left(2.947517^{\circ} \mathrm{N} ;-78.198133^{\circ} \mathrm{W}\right)$. The specimen was collected and stored in a plastic container with seawater. Later, it was observed under a stereomicroscope and photographed (Figure 2). Next, it was relaxed with the gradual addition of freshwater to the containing recipient and, after death, fixed and preserved in $97 \%$ ethanol. At the laboratory, the specimen was measured, photographed, and stored in the Reference Collection of Marine Organisms (Biology Department, Universidad del Valle, Cali, Colombia).

According to WoRMS (2020), the following is the current, valid, and accepted taxonomy for the specimen collected at Gorgona Island:

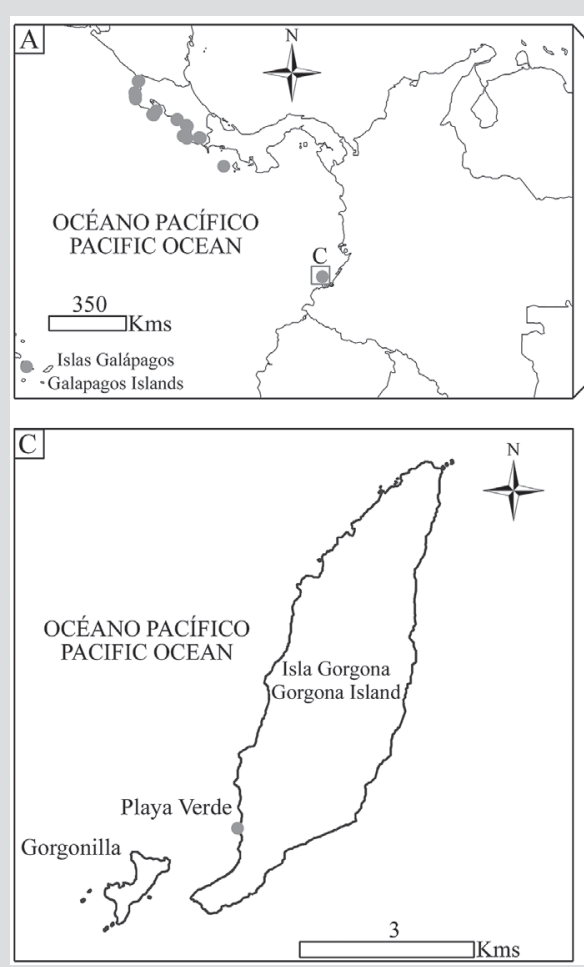

Figura 1. Localidades donde Titiscania limacina ha sido registrada, mostrando su distribución en el PTO (A), el Indo-Pacífico y el Pacífico Occidental (B) y el sitio en la isla Gorgona (C) sobre la costa Pacífica de Colombia. Datos de GBIF [https://doi.org/10.15468/dl.6hgpgh; Templado y Ortea (2001); Apte y Nerurkar (2016)].

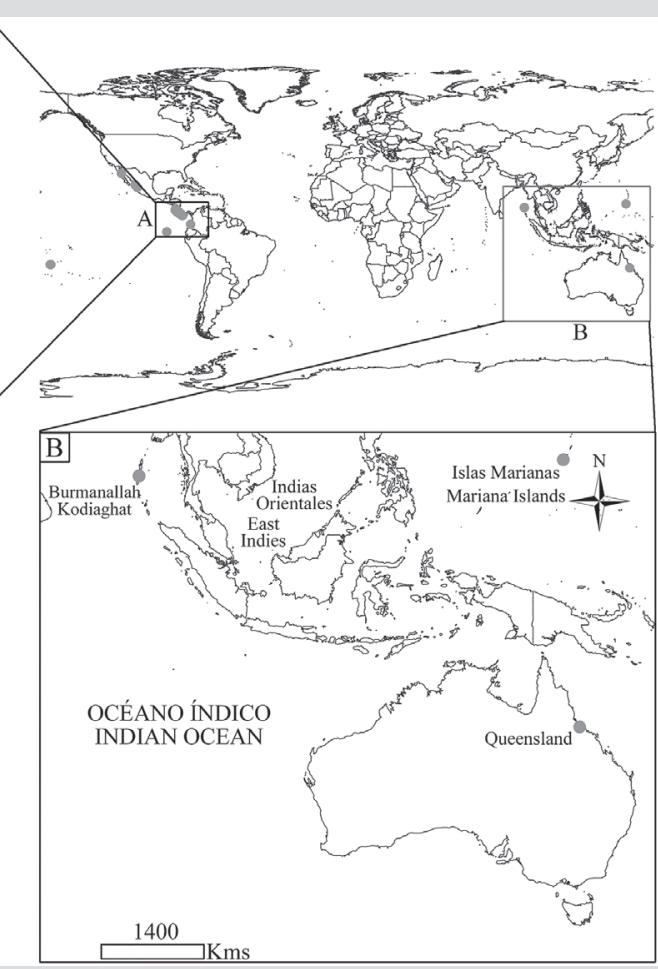

Figure 1. Localities where Titiscania limacina has been recorded, showing its distribution in the TEP (A), the Indo-Pacific and West Pacific (B), and the site at Gorgona Island (C) on the Pacific coast of Colombia. Data from GBIF [https://doi.org/10.15468/dl.6hgpgh; Templado and Ortea (2001); Apte and Nerurkar (2016)]. 
De acuerdo con WoRMS (2020), la siguiente es la taxonomía actual, válida y aceptada del espécimen recolectado en la isla Gorgona:

\section{Clase Gastropoda Cuvier, 1795}

Subclase Neritimorpha Golikov \& Starobogatov, 1975

Orden Cycloneritida Frýda, 1998

Superfamilia Neritopsoidea Gray, 1847

Familia Neritopsidae Gray, 1847

Subfamilia Neritopsinae Gray, 1847

Género Titiscania Bergh, 1890

\section{Especie Titiscania limacina Bergh, 1890}

Aunque no se midió en el campo, el espécimen oscilaba entre 10 y $15 \mathrm{~mm}$ en longitud. Cuando se tocó, antes de recolectarlo, el espécimen destelló una serie de puntos blancos uniformemente espaciados a lo largo de líneas paralelas en su parte dorsal (notum), que se extendían desde casi cuatro quintos de la longitud del cuerpo desde la cabeza hasta la cola. Este comportamiento y el hecho de que el animal secretara una sustancia defensiva (no observado esta vez) desde los puntos blancos ha sido registrado con anterioridad (Templado and Ortea, 2001; Apte and Nerurkar, 2016).

La identificación del espécimen fue posible gracias a la fotografía en el cartel "Strange and unusual small molluscs from Madang”. El cartel salió de la expedición a Papua Niugini, liderada por el Dr. Philippe Bouchet del Museo Nacional de Historia Natural (París, Francia). Después de una corta comunicación, el Dr. Bouchet confirmó la identificación del espécimen recolectado en Gorgona como Titiscania limacina. La identificación fue reconfirmada siguiendo la descripción en Bergh (1890). En el laboratorio, el espécimen fijado midió $17 \mathrm{~mm}$ de largo (Figura 2). Este se incluyó en la colección con el número de registro CRM-UV:RMO2019-041.

Dado los números conocidos hasta el momento, el POT no es considerado como una región marina altamente biodiversa, al menos si se le compara con el Indo-Pacífico y el Atlántico Tropical Occidental (Bouchet et al., 2016); sin embargo, su biodiversidad marina puede estar siendo subestimada debido a que los esfuerzos de investigación taxonómica son más bien débiles comparados con el IndoPacífico, por ejemplo. En Colombia, la costa Pacífica ha estado históricamente detrás de la costa Caribe en la investigación biológica. Las dificultades para el acceso (transporte limitado) y asuntos de seguridad pública son quizás las principales razones. Estas han impedido por años la investigación en la región, excepto en algunos lugares como isla Gorgona y
Class Gastropoda Cuvier, 1795

Subclass Neritimorpha Golikov \& Starobogatov, 1975

Order Cycloneritida Frýda, 1998

Superfamily Neritopsoidea Gray, 1847

Family Neritiopsidae Gray, 1847

Subfamily Neritopsinae Gray, 1847

Genus Titiscania Bergh, 1890

Species Titiscania limacina Bergh, 1890

In the field, although not measured, the specimen ranged from 10 to $15 \mathrm{~mm}$ in length. When touched, before collection, the specimen flashed a series of evenly spaced white dots along parallel lines on its back (notum), extending almost four-fifths of the length of the body from head to tail. This behavior and the fact that the animal secretes a defensive substance (not observed this time) from those dots have been reported elsewhere (Templado and Ortea, 2001; Apte and Nerurkar, 2016).

The identification of the specimen was possible thanks to a picture depicted in the poster: "Strange and unusual small molluscs from Madang". The poster came from the Papua Niugini expedition, led by Dr. Philippe Bouchet from the Muséum National d'Histoire Naturelle (Paris, France). After a short communication, Dr. Bouchet confirmed the identification of the specimen collected at Gorgona as Titiscania limacina. The identification was reconfirmed following the description in Bergh (1890). At the laboratory, the fixed specimen measured $17 \mathrm{~mm}$ in length (Figure 2). It was included in the collection with the number CRM-UV:RMO2019-041.

Given the currently known figures, the TEP is not regarded as a highly biodiverse marine region, at least compared to the Indo-Pacific and the East and West Tropical Atlantic (Bouchet et al., 2016); however, its marine biodiversity could be underestimated because the taxonomic research efforts are rather languid as compared, for example, to the Indo-Pacific. In Colombia, the Pacific coast has historically lagged behind the Caribbean coast in biological research. The difficulty in access (limited transportation) and issues of public security are perhaps the main reasons. These have hindered research in the region for years, except in few sites such as Gorgona Island and Malaga Bay, where scientists have been welcomed and have inventoried much of the biodiversity of well-known biological groups (e.g., fishes, mollusks, and echinoderms). However, even in these groups, new records of uncommon or cryptic species are 


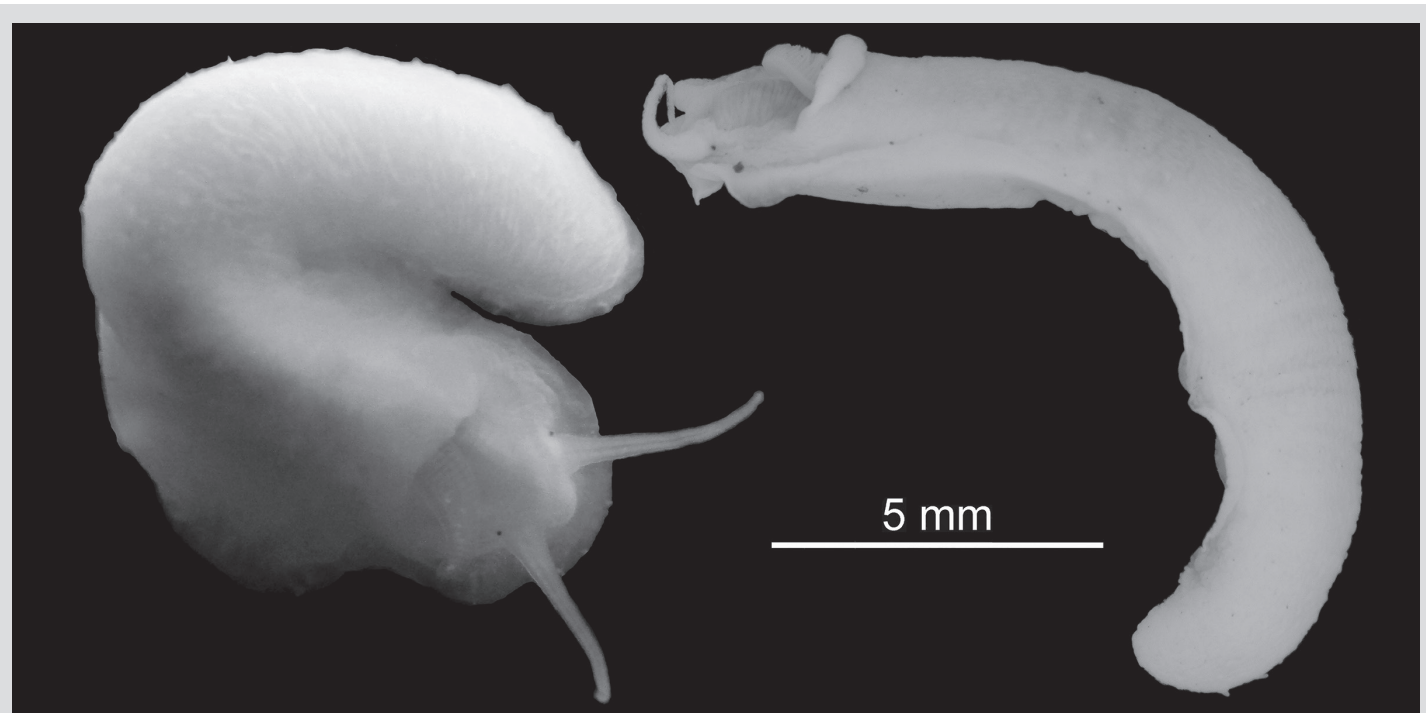

Figura 2. Titiscania limacina viva (izq.) y preservada (der.). Los tentáculos, ojos y branquia pueden verse fácilmente. La escala corresponde a la foto del animal preservado (CLaboratorio de Imágenes, Posgrado en CienciasBiología, Universidad del Valle, Ortega and Londoño-Cruz).
Figure 2. Titiscania limacina alive (left) and preserved (right). The tentacles, eyes, and gill are easily seen. Scale bar is for the picture of the preserved animal. Preserved specimen picture (CLaboratorio de Imágenes, Posgrado en Ciencias-Biología, Universidad del Valle, Ortega and Londoño-Cruz). bahía Malaga, donde los científicos han sido bienvenidos y han hecho inventario de la biodiversidad de grupos biológicos bien conocidos ( $v . g$. peces, moluscos y equinodermos). Sin embargo, incluso en estos grupos, nuevos registros de especies poco comunes o crípticas son registrados con frecuencia. López de Mesa y Cantera (2015) registraron 426 especies de moluscos, de las cuales 44 fueron nuevos registros. El registro de esta babosa marina es solo una pequeña contribución, pero datos recientes para el mismo o lugares similares (ValenciaGiraldo et al., 2015; Muñoz y Londoño-Cruz, 2016; LondoñoCruz et al., 2018) dan esperanzas de obtener resultados interesantes y prometedores en los inventarios futuros sobre biodiversidad si se da más apoyo y se hacen esfuerzos en la investigación biológica a lo largo de la región.

Para concluir, este documento registra por primera vez la presencia de $T$. limacina en la costa Pacífica de Colombia, específicamente en el ecosistema rocoso de la isla Gorgona. Esto llena un vacío en la distribución de esta babosa marina en el POT y confirma su presencia en todos los países que forman parte del corredor marino del POT.

\section{AGRADECIMIENTOS}

Se agradece al Dr. Philippe Bouchet por su ayuda en la identificación de la especie. Al personal del Parque Nacional Natural Gorgona, particularmente a Ximena Zorrilla, Luis Payán y Hector "Chirimías" González, que dieron apoyo logístico. A los biólogos María Fernanda Cardona-Gutiérrez y often reported. López de Mesa and Cantera (2015) reported 426 species of mollusks of which 44 were new records. The report of this sea-slug is just a small contribution, but the recent similar results for the same or similar sites (ValenciaGiraldo et al., 2015; Muñoz and Londoño-Cruz, 2016; Londoño-Cruz et al., 2018) rise hope for promising and interesting results in the biodiversity inventories to come, if more effort and support are put into biological research across the region.

To conclude, this paper reports for the first time the presence of T. limacina on the Pacific coast of Colombia, specifically in the rocky ecosystem of Gorgona Island. This fills a gap in the distribution of this sea-slug in the TEP and confirms its presence in all the countries that are part of the TEP Marine Corridor.

\section{ACKNOWLEDGMENTS}

The author wants to thank Dr. Philippe Bouchet for his help in species identification. The personnel at Gorgona National Natural Park, particularly Ximena Zorrilla, Luis Payán, and Hector "Chirimías" González, provided logistic support. Biologists María Fernanda Cardona-Gutiérrez and Kevin Mendoza aided during fieldwork. Juan Carlos Mejía prepared the distribution map (Figure 1), Juan Felipe Ortega photographed the preserved animal, and Dr. Jaime Cantera provided literature and red the first draft. Permit 178 of the National Natural Parks of Colombia (Ministry 
Kevin Mendoza, que ayudaron durante el trabajo de campo. Juan Carlos Mejía preparó el mapa de distribución (Figura 1), Juan Felipe Ortega fotografió el animal preservado y el Dr. Jaime Cantera aportó literatura y leyó el primer borrador. El permiso 178 de Parques Nacionales Naturales de Colombia (Ministerio de Ambiente y Desarrollo Sostenible) permitió la recolección del espécimen. Contribución 15 del Instituto de Ciencias del Mar y Limnología (Incimar) de la Universidad del Valle. of Environment and Sustainable Development) allowed the collection of the specimen. Contribution 15 from the Universidad del Valle's Institute of Marine Sciences and Limnology (Incimar).

\section{BIBLIOGRAFÍA/LITERATURE CITED}

Appeltans, W., Ahyong, S.T., Anderson, G., Angel, M.V., Artous, T., Bailly, N., et al. 2012. The magnitude of global marine species diversity. Curr Biol., 22(23): 2189-202. https://doi.org/10.1016/j.cub.2012.09.036

Apte, D. and S. Nerurkar. 2016. First record of Titiscania limacina Bergh, 1890 (Mollusca: Gastropoda) from India. J. Bombay Nat. Hist. Soc., 112(3): $22-25$.

Bergh, R. 1890. Die Titiscanien, eine Familie der rhipidoglossen Gastropoden. Morpholog. Jahrb., 16: 1-26 + pl. 1-3.

Bouchet, P. 2006. The magnitude of marine biodiversity. 31-64. In: Duarte, C.M. (Ed.). The exploration of marine biodiversity: scientific and technological challenges. Fundación BBVA, Bilbao. 158 p.

Bouchet, P., S. Bary, V. Héros, and G. Marani. 2016. How many species of molluscs are there in the world's oceans, and who is going to describe them? 9-24. In: Héros, V., E. Strong, and P. Bouchet. (Eds). Tropical Deep-Sea Benthos, (29). Mémoirs du Muséum national d’Histoire naturelle, tome 208. Muséum national d'Histoire naturelle, Paris. 463 p.

Foggo, A., S.D. Rundle, and D.T. Bilton. 2003. The net result: evaluating species richness extrapolation techniques for littoral pond invertebrates. Freshw Biol., 48: 1756-1764.

GBIF Secretariat. 2019. Titiscania limacina Bergh, 1890 in GBIF Backbone Taxonomy. Checklist dataset https://doi.org/10.15468/39omei accessed via GBIF. org 2020-06-13.

Londoño-Cruz, E., L.D. Obonaga, and M. Zucconi-Ramírez. 2018. First record of Echinothrix calamaris (Echinoidea: Diadematidae) in the Colombian Pacific. Mar. Biodiv. Rec., 11(15). https://doi.org/10.1186/s41200-018-0150-5

López de Mesa, L.A. and J. Cantera. 2015. Marine mollusks of Bahía Málaga, Colombia (Eastern Tropical Pacific). Check List 11(1): 1497. http://dx.doi. org/10.15560/11.1.1497

Miloslavich, P., E. Klein, J.M. Díaz, C.E. Hernández, G. Bigatti, L. Campos, F. Artigas, J. Castillo, P.E. Penchaszadeh, P.E. Neill, A. Carranza, M.V. Retana, J.M. Díaz de Astarloa, M. Lewis, P. Yorio, M.L. Piriz, D. Rodríguez, Y. Yoneshigue-Valentin, L. Gamboa, and A. Martín. 2011. Marine biodiversity in the Atlantic and Pacific coasts of South America: knowledge and gaps. PLoS One. https://doi.org/10.1371/journal.pone.0014631

Mora, C., D.P. Tittensor, S. Adl, A.G.B. Simpson, and B. Worm. 2011. How many species are there on earth and in the ocean? PLoS Biol. https://doi.org/10.1371/ journal.pbio. 1001127

Muñoz, C.G. and E. Londoño-Cruz. 2016. First record of the irregular sea urchin Lovenia cordiformis (Echinodermata: Spatangoida: Loveniidae) in Colombia. Mar. Biodiv. Rec., 9(67). https://doi.org/10.1186/s41200-016-0022-9

South American Research Group on Coastal Ecosystems. 2012. Protocol and sampling design for marine diversity assessments for the South American Research Group on Coastal Ecosystems. South Am. Res. Group Coast. Ecosyst., Caracas. 12 p. http://dx.doi.org/10.25607/OBP-5

Tamsouri, N., L. Carmona, A. Moukrim, and J.L. Cervera. 2014. Description of a new species of Piseinotecus (Gastropoda, Heterobranchia, Piseinotecidae) from the northeastern Atlantic Ocean. Bull. Mar. Sci., 90(4): 991-997. http://dx.doi.org/10.5343/bms.2014.1019

Tan, K.S. and L.L. Liu. 2001. Description of a new species of Thais (Mollusca: Neogastropoda: Muricidae) from Taiwan, based on morphological and allozyme analyses. Zool. Sci., 18: 1275-1289.

Templado, L. and J. Ortea. 2001. The occurrence of the shell-less neritacean gastropod Titiscania limacina in the Galapagos Islands. The Veliger, 44(4): 404-406.

Valencia-Giraldo, D., J.F. Lazarus, and E. Londoño-Cruz. 2015. New records of decapod species from Malpelo Island, Tropical Eastern Pacific. Mar. Biodivers. https://doi.org/10.1007/s12526-015-0401-1

WoRMS. 2020. Titiscania limacina Bergh, 1890. http://www.marinespecies.org/aphia.php?p=taxdetails\&id=532065. 2020-06-28. 